\title{
Is Dipeptidyl Peptidase IV (DPP IV) Associated with Inflammation Present in Human Spondyloarthritides and Rheumatoid Arthritis? ${ }^{\dagger}$
}

\author{
Dijana Detel, ${ }^{a}$ Tatjana Kehler, ${ }^{b}$ Sunčica Buljević, ${ }^{a}$ Irena Pavačić, ${ }^{c}$ \\ Lara Batičić Pučar, ${ }^{\mathrm{a}}$ Neven Varljen, ${ }^{\mathrm{d}}$ and Jadranka Varljen ${ }^{\mathrm{a}, *}$ \\ ${ }^{a}$ Department of Chemistry and Biochemistry, School of Medicine, University of Rijeka, \\ Braće Branchetta 20, HR-51000 Rijeka, Croatia \\ ${ }^{\mathrm{b}}$ Department of Rheumatology, Thalassotherapy Hospital Opatija, School of Medicine, University of Rijeka, \\ Braće Branchetta 20, HR-51000 Rijeka, Croatia \\ ${ }^{\mathrm{c}}$ School of Medicine, University of Rijeka, Braće Branchetta 20, HR-51000 Rijeka, Croatia \\ ${ }^{\mathrm{d}}$ Department of Physical Medicine and Rehabilitation, Thalassotherapy Hospital Opatija, School of Medicine, \\ University of Rijeka, Braće Branchetta 20, HR-51000 Rijeka, Croatia
}

RECEIVED DECEMBER 17, 2010; REVISED JUNE 15, 2011; ACCEPTED MAY 8, 2012

\begin{abstract}
Dipeptidyl peptidase IV (DPP IV) is a serine peptidase which has been suggested to play a role in the pathogenesis of rheumatoid arthritis, but its mediator actions have not been well investigated in patients with spondyloarthritides. The purpose of this study was to investigate clinical relevance of changes in serum DPP IV activity and concentration in these diseases. Serum DPP IV activity was significantly decreased in patients with spondyloarthritides and rheumatoid arthritis compared to the control group, while DPP IV concentration was increased. Among spondyloarthritides patients, DPP IV concentration was decreased in patients with reactive arthritis. No difference was observed in DPP IV activity or concentration between spondyloarthritides and rheumatoid arthritis, as well as between patients with clinically active disease and those in remission. Our results suggest that DPP IV could not be used as a specific serum marker, but could be potentially used as a non-specific inflammatory marker. (doi: 10.5562/cca1863)
\end{abstract}

Keywords: dipeptidyl peptidase IV, spondyloarthritides, rheumatoid arthritis

\section{INTRODUCTION}

Spondyloarthritides $(\mathrm{SpA})$ and rheumatoid arthritis (RA) are autoimmune inflammatory diseases characterized by chronic inflammation of joints leading to their progressive and irreversible destruction. ${ }^{1} \mathrm{SpA}$ are a heterogeneous group of related diseases, including psoriatic arthritis (PsA), ankylosing spondylitis (AS) and reactive arthritis (ReA) which commonly share similar epidemiological, clinical and radiological features, as well as pathogenetic mechanisms. ${ }^{2-6}$ Inflammatory processes that are associated with rheumatic diseases are regulated by exogenous and endogenous factors, including cytokines, chemokines and peptidases. Cytokines and chemokines, particularly stromal derived factor-1 $\alpha$ (SDF-1 $\alpha)$ and tumour necrosis factor $\alpha$ $(\mathrm{TNF} \alpha)$, are implicated in each phase of the pathogenesis by promoting autoimmunity and by maintaining chronic synovitis and tissue destruction. ${ }^{7}$ Furthermore, it has been suggested that cell surface peptidases play an important role in the activation or inactivation of mediators involved in the occurrence and perpetuance of inflammatory processes. ${ }^{8}$

Dipeptidyl peptidase IV (DPP IV; EC 3.4.14.5), known as CD26 molecule is a widely expressed multifunctional glycoprotein present both on the cell surface of various tissues and as a soluble form in plasma and other biological fluids. As a serine protease, DPP IV cleaves the $\mathrm{N}$-terminal dipeptides from proteins having either proline or alanine at the penultimate position. Numerous biologically active polypeptides like hormones, cytokines, and chemokines share this sequence and are potential substrates. Experimental and clinical data indicate an important role of DPP IV in degradation of SDF- $1 \alpha, \mathrm{TNF} \alpha$ and many other inflammatory molecules. ${ }^{9}$ Furthermore, several studies point out the involvement of CD26 in T lymphocyte activation and proliferation which results in the change of the Th1/Th2

\footnotetext{
$\dagger$ Presented at the $10^{\text {th }}$ Congress of the Croatian Society of Biochemistry and Molecular Biology held in Opatija, Croatia, September 15-18, 2010.

* Author to whom correspondence should be addressed. (E-mail: vjadran@medri.hr)
} 
balance towards a Th1-like reaction. ${ }^{10}$ Therefore, DPP IV could be implicated in the modulation of the immune response.

In rheumatic diseases, as chronic inflammatory immune-mediated disorders, DPP IV as a protease and/or CD26 antigen may have a dual role: on the one hand stimulating cellular immunity, and on the other modulating chemokine functions. A number of studies have shown that, in RA patients, DPP IV activity or CD26 antigen levels in serum as well as in synovial membrane were changed in comparison to controls, but there is no such data for SpA patients. DPP IV inhibitors have been shown to suppress migration of $\mathrm{T}$ lymphocyte subpopulation into the inflamed tissue, as well as suppressing T cell DNA synthesis and production of $\mathrm{TNF} \alpha$ and interleukin-11. Although there is a lot of evidence about the importance of DPP IV in immunomodulation, its precise role in the ethiopathogenesis of rheumatic diseases is not entirely clear.

Based on the described potential role of DPP IV in the modulation of immune response, we hypothesized that serum DPP IV activity and concentration are altered in various rheumatic diseases, including PsA, AS and ReA. The aim of this study was to estimate the clinical relevance of changes in serum DPP IV activity and concentration, which could be connected to disease activity and might therefore be useful as a distinguishing diagnostic marker among $\mathrm{SpA}$ diseases.

\section{MATERIALS AND METHODS}

\section{Patients}

Patients included in this study were recruited at the Department of Rheumathology, Thalassotherapy Hospital, School of Medicine, University of Rijeka, Croatia. The study was performed according to the principals of the Declaration of Helsinki and was approved by the Ethics Committee for Medical Research, School of Medicine, University of Rijeka. All involved patients signed the informed consent. The study included 239 patients with different categories of inflammatory arthritis and 65 healthy controls. Clinical characteristics and demographic data which included age, sex and disease duration, as well as blood samples, were collected from each of these patients and presented in the Table I. According to the clinical presentation and laboratory data, patients were divided into two groups: RA patients and SpA patients who include PsA, AS and ReA patients. Furthermore, patients in each group were divided into two subgroups depending on the disease activity.

\section{Patients with $\operatorname{SpA}$}

The study included $180 \mathrm{SpA}$ patients who fulfilled the European Spondylarthropaty Study Group criteria for the disease. ${ }^{11}$ Among SpA patients 98 had PsA, 52 had AS and 30 had ReA. The classification of PsA patients was based on the presence of an inflammatory articular

Table 1. Demographic and clinical characteristics of patients with spondyloarthritides and rheumatoid arthritis

\begin{tabular}{|c|c|c|c|c|c|c|c|c|}
\hline \multirow{2}{*}{ Diagnosis } & \multicolumn{2}{|c|}{ PsA } & \multicolumn{2}{|c|}{ AS } & \multicolumn{2}{|c|}{$\operatorname{ReA}$} & \multicolumn{2}{|c|}{ RA } \\
\hline & A & $\mathrm{R}$ & A & $\mathrm{R}$ & A & $\mathrm{R}$ & A & $\mathrm{R}$ \\
\hline Number & 48 & 50 & 31 & 21 & 19 & 11 & 29 & 30 \\
\hline $\begin{array}{l}\text { Age / years } \\
\text { median (range) }\end{array}$ & $\begin{array}{c}51 \\
(21-70)\end{array}$ & $\begin{array}{c}53 \\
(31-76)\end{array}$ & $\begin{array}{c}43 \\
(16-74)\end{array}$ & $\begin{array}{c}28 \\
(18-66)\end{array}$ & $\begin{array}{c}52 \\
(19-65)\end{array}$ & $\begin{array}{c}47 \\
(35-60)\end{array}$ & $\begin{array}{c}55 \\
(36-80)\end{array}$ & $\begin{array}{c}63 \\
(41-76)\end{array}$ \\
\hline Male:female ratio & $22: 26$ & $18: 32$ & $25: 6$ & $5: 16$ & $7: 12$ & $4: 7$ & $7: 22$ & $3: 27$ \\
\hline Swollen joint count & $39^{(\mathrm{a})} / 6^{(\mathrm{b})} / 3^{(\mathrm{c})}$ & $49^{(\mathrm{a})} / 0^{(\mathrm{b})} / 1^{(\mathrm{c})}$ & - & - & $15^{(\mathrm{a})} / 1^{(\mathrm{b})} / 3^{(\mathrm{c})}$ & $11^{(\mathrm{a})} / 0^{(\mathrm{b})} / 0^{(\mathrm{c})}$ & $8^{(\mathrm{a})} / 11^{(\mathrm{b})} / 10^{(\mathrm{c})}$ & $28^{(\mathrm{a})} / 2^{(\mathrm{b})} / 0^{(\mathrm{c})}$ \\
\hline Tender joint count & $17^{(\mathrm{a})} / 7^{(\mathrm{b})} / 24^{(\mathrm{c})}$ & $50^{(\mathrm{a})} / 0^{(\mathrm{b})} / 0^{(\mathrm{c})}$ & - & - & $11^{(\mathrm{a})} / 2^{(\mathrm{b})} / 6^{(\mathrm{c})}$ & $11^{(\mathrm{a})} / 0^{(\mathrm{b})} / 0^{(\mathrm{c})}$ & $2^{(\mathrm{a})} / 8^{(\mathrm{b})} / 19^{(\mathrm{c})}$ & $25^{(\mathrm{a})} / 4^{(\mathrm{b})} / 1^{(\mathrm{c})}$ \\
\hline Rheumatoid factor & - & - & - & - & - & - & 27 & 26 \\
\hline $\begin{array}{c}\text { DAS } 28 \\
\text { median (range) }\end{array}$ & $\begin{array}{c}4.1 \\
(0.6-6.8)^{(\mathrm{d})}\end{array}$ & $\begin{array}{c}2.0 \\
(0.6-4.49)\end{array}$ & - & - & $\begin{array}{c}3.8 \\
(2.1-6.2)^{(\mathrm{d})}\end{array}$ & $\begin{array}{c}1.7 \\
(1.5-2.7)\end{array}$ & $\begin{array}{c}5.13 \\
(3.5-7.4)^{(\mathrm{d})}\end{array}$ & $\begin{array}{c}2.5 \\
(0.9-2.5)\end{array}$ \\
\hline Psoriasis (positive) & 29 & 20 & - & - & - & - & - & - \\
\hline $\begin{array}{l}\text { Schober's test } \\
\text { median (range) }\end{array}$ & - & - & $\begin{array}{c}3.0 \\
(1.0-6.0)\end{array}$ & $\begin{array}{c}4.0 \\
(0.5-6.5)\end{array}$ & - & - & - & - \\
\hline $\begin{array}{c}\text { BASDAI } \\
\text { median (range) }\end{array}$ & - & - & $\begin{array}{c}6.4^{(\mathrm{d})} \\
(4.5-8.9)\end{array}$ & $\begin{array}{c}3.9 \\
(3.9-3.9)\end{array}$ & - & - & - & - \\
\hline Peripheral arthritis / \% & - & - & 29.0 & 47.6 & - & - & - & - \\
\hline Sacroileitis / \% & - & - & - & - & 47.3 & 54.5 & - & - \\
\hline
\end{tabular}

PsA, psoriatic arthritis; AS, ankylosing spondylitis; ReA, reactive arthritis; RA, rheumatoid arthritis; A, active; R, remission; DAS 28, disease activity score 28; BASDAI, bath ankylosing spondylitis disease activity index.

(a) Number of joints: $<4$.

(b) Number of joints: $4-8$.

(c) Number of joints: $>8$.

(d) Statistically significantly increased compared to remission, $p<0.050$. 
disease, according to the Moll and Wright criteria, ${ }^{12}$ and psoriasis was confirmed clinically by the dermatologist. The disease activity was defined by the presence of swollen and tender joints together with erythrocyte sedimentation rate (ESR) and C-reactive protein concentration (CRP) as laboratory parameters of inflammation. The clinical activity of AS patients was evaluated using the Bath Ankylosing Spondylitis Disease Activity Index (BASDAI) together with ESR and CRP, according to The Assessment in Ankylosing Spondylitis Criteria for AS. ${ }^{13}$ In these patients, early morning stiffness, Schober's test, sagital indices for each part of the spine and HLA-B27 test were also evaluated. The disease activity in ReA patients was assessed equally as in PsA patients. In addition, swollen and tender joints, sacroiliitis and extra-articular manifestations (uveitis) were also evaluated in those patients.

\section{Patients with RA}

The study group included 59 RA patients diagnosed according to the American College of Rheumatology criteria. ${ }^{14,15}$ For each patient, 28-joint disease activity score (DAS 28) was calculated using swollen joint count (0-28), tender joint count (0-28) and ESR. Rheumatoid factor, CRP values and early morning stiffness were also recorded. According to the DAS 28, patients were classified as those with active disease and those in remission (Table 1). Joint counts were performed by a single trained assessor in all groups.

\section{Control group}

The control group consisted of 65 healthy donors (32 males and 33 females; mean age $42 \pm 12$ years) without symptoms of inflammatory joint disease or any other inflammatory conditions.

\section{Blood Samples}

Blood samples were obtained at the initial and/or follow up visits, collected in dry tubes and centrifuged for 12 minutes at $4000 \mathrm{rpm}$. Serum aliquots were immediately frozen at $-80{ }^{\circ} \mathrm{C}$ until analysis and used for the assessment of laboratory parameters, DPP IV activity and concentration. Laboratory parameters included ESR, CRP, imunoglobulin (Ig) A, IgG and IgM levels, erythrocytes, leucocytes, platelet, total iron binding capacity, total proteins, globulin fractions and albumin concentration.

\section{DPP IV Activity Assay}

Serum DPP IV enzyme activity was measured by a substrate conversion assay according to the protocol of Kreisel et al. ${ }^{16}$ DPP IV activity was determined spectrofotometrically by measuring the release of 4nitroaniline from an assay mixture containing $0.1 \mathrm{M}$ Tris $\mathrm{HCl}$ buffer $(\mathrm{pH}=8)$, chromogenic substrate Gly-
Pro-p-nitroanilide (Sigma Chemical, Steinheim, Germany) and enzyme in a total volume of $0.20 \mathrm{~mL}$. After 30 min incubation at $37{ }^{\circ} \mathrm{C}$, the reaction was stopped by addition of $0.8 \mathrm{~mL}$ of sodium acetate buffer $(c=1 \mathrm{~mol}$ $\mathrm{dm}^{-3}, \mathrm{pH}=4.5$ ). Absorbance was measured at $\lambda=405$ $\mathrm{nm}$ using a Varian Cary $100 \mathrm{UV} / \mathrm{Vis}$ spectrophotometer (Cary, NC, USA). All reactions were performed in duplicate. Enzyme activities were expressed as international units per liter of serum. One unit corresponds to the hydrolysis of $1 \mu \mathrm{mol}$ of substrate per minute under assay conditions.

\section{Serum DPP IV immunodetection}

The measurement of DPP IV serum concentrations in patients with PsA, AS, ReA and RA was assessed by sandwich enzyme-linked immunosorbent assay ("Duo set" ELISA kit - DY1180, R\&D Systems, UK) according to the manufacturer's instructions. A microplate reader Bio-Tek (EL808, USA) was used to measure absorbance at $\lambda=450 \mathrm{~nm}$. A wavelength correction was performed at $\lambda=570 \mathrm{~nm}$.

\section{Statistical Analysis}

The collected data were statistically evaluated using the data analysis software system STATISTICA, version 8.0. (StatSoft, Inc. Tulsa, USA). All data are reported as median and range, except where otherwise indicated. To test the differences between analyzed parameters, the Kruskal-Wallis and Mann-Whitney U test were used. Qualitative data were analysed using chi-square test. Spearman's test was used to calculate correlation, as indicated in the text. $P$ values less than 0.050 were considered to be statistically significantly different.

\section{RESULTS}

\section{Patients' Demographic and Clinical Characteristics}

Demographic and clinical characteristics of $\mathrm{SpA}$ and RA patients with active disease and those in remission are reported in Table 1. Pairwise test showed that both groups of RA patients were older compared to the patients with AS and ReA and to the controls $(42 \pm 12$ years). However, in the SpA group, PsA and ReA patients were older in comparison with AS.

The proportion of female patients in both RA groups was statistically significantly higher, whereas in AS groups the proportion of male patients was statistically significantly higher. In other groups, chi-square test did not show statistically significant difference between male and female distribution.

Among RA patients, 53 tested were positive for rheumatoid factor, 27 with active disease and 26 in remission. At the time of evaluation, psoriatic skin manifestations were observed in $60.4 \%$ active PsA patients 


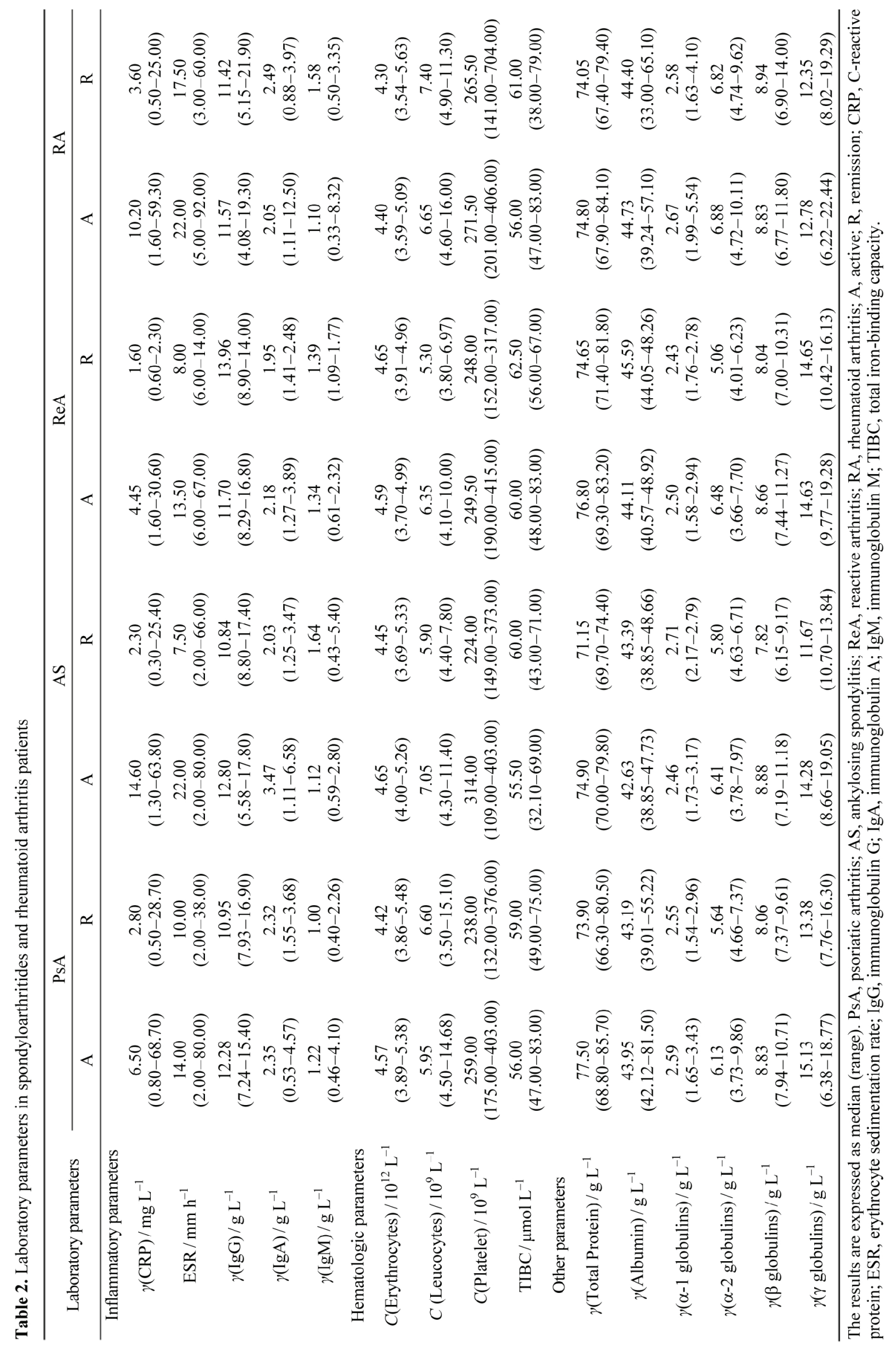


Table 3. Influence of disease activity on serum dipeptidyl peptidase IV (DPP IV) activity $\left(z / \mathrm{IU} \mathrm{L}^{-1}\right)$ and mass concentration in patients with spondyloarthritides and rheumatoid arthritis

\begin{tabular}{|c|c|c|c|}
\hline Diagnosis & $\begin{array}{l}\text { Disease } \\
\text { activity }\end{array}$ & $\begin{array}{c}z \text { (DPP IV) } / \\
\text { IU L L }^{-1}\end{array}$ & $\begin{array}{c}\gamma(\text { DPP IV }) / \\
\text { ng mL }^{-1}\end{array}$ \\
\hline \multirow{2}{*}{ PsA } & A & $\begin{array}{c}32.5 \\
(8.0-84.5)\end{array}$ & $\begin{array}{c}265.6 \\
(176.0-388.0)\end{array}$ \\
\hline & $\mathrm{R}$ & $\begin{array}{c}41.5 \\
(14.4-90.7)\end{array}$ & $\begin{array}{c}208.0 \\
(139.3-418.3)\end{array}$ \\
\hline \multirow{2}{*}{ AS } & A & $\begin{array}{c}38.0 \\
(18.4-81.9)\end{array}$ & $\begin{array}{c}237.2 \\
(144.4-445.0)\end{array}$ \\
\hline & $\mathrm{R}$ & $\begin{array}{c}34.9 \\
(12.2-88.1)\end{array}$ & $\begin{array}{c}249.0 \\
(107.2-401.0)\end{array}$ \\
\hline \multirow{2}{*}{ ReA } & A & $\begin{array}{c}38.4 \\
(20.7-69.1)\end{array}$ & $\begin{array}{c}185.4 \\
(108.3-234.9)\end{array}$ \\
\hline & $\mathrm{R}$ & $\begin{array}{c}41.3 \\
(31.8-44.1)\end{array}$ & $\begin{array}{c}189.5 \\
(109.9-234.3)\end{array}$ \\
\hline \multirow{2}{*}{ RA } & A & $\begin{array}{c}33.9 \\
(14.5-67.9)\end{array}$ & $\begin{array}{c}235.2 \\
(116.2-372.7)\end{array}$ \\
\hline & $\mathrm{R}$ & $\begin{array}{c}33.6 \\
(12.1-78.6)\end{array}$ & $\begin{array}{c}228.2 \\
(114.2-409.2)\end{array}$ \\
\hline
\end{tabular}

Values are expressed as median (range). PsA, psoriatic arthritis; AS, ankylosing spondylitis; ReA, reactive arthritis; RA, rheumatoid arthritis; A, active; R, remission.

and $40.0 \%$ of those in remission, while psoriasis mean duration was $19 \pm 13$ years in the PsA group. For each AS patient, spinal flexibility was measured by Schober's test (Table 1) and by indices of sagital movement for cervical, thoracal and lumbosacral segment of the spine. Median of indices for active AS patients was 12.0 (2.0$15.0), 4.0(1.0-6.0)$ and $5.0(2.0-10.0)$ and for those in remission $13.0(4.0-16.0), 6.0(3.0-8.0)$ and $7.0(1.0-$ $10.0)$, respectively. Furthermore, extra-articular manifestations were present in 11 ReA patients and 17 of them had anterior uveitis positive for Chlamydia trachomatis.

All determined laboratory parameters are summarized in Table 2. Serum CRP and ESR values of RA, PsA and AS patients who showed active disease symptoms were statistically significantly increased in comparison to those in remission, unlike ReA patients. In RA and ReA group serum CRP level correlated statistically significantly with DAS 28 (Spearman's test: $r=$ $0.58 ; r=0.35, p<0.050$ ). Finally, we did not observe any significant differences among other laboratory parameters between patients with active disease and those in remission in $\mathrm{SpA}$ or RA groups.

\section{Serum DPP IV Activity and Concentration}

Circulating DPP IV activity was significantly decreased in SpA (median: $36.3 \mathrm{IU} \mathrm{L}^{-1}$; range: $8.0-90.7$ ) and RA patients (median: $33.6 \mathrm{IU} \mathrm{L}^{-1}$; range 12.1-78.6) compared to the control group (median: $45.8 \mathrm{IU} \mathrm{L}^{-1}$; range: 36.8-79.0) (Figure 1a). No difference was observed in serum DPP IV activity between SpA and RA patients (Figure 1a). The immunodetection of DPP IV in serum did not demonstrate a significant difference between DPP IV concentration in SpA (median $220.6 \mathrm{ng} \mathrm{mL}^{-1}$; range: $107.2-445.1$ ) and $\mathrm{RA}$ (median $230.1 \mathrm{ng} \mathrm{mL}^{-1}$; range: $114.2-409.2$ ) patients, but a significant difference was observed in comparison to the control group (median $164.9 \mathrm{ng} \mathrm{mL}^{-1}$; range 114.4-315.3) for both SpA and RA (Figure 1b).

Among SpA patients, there was no statistically significant difference between serum DPP IV activities in each group. DPP IV activity in PsA (median: 35.8 $\mathrm{IU} \mathrm{L}^{-1}$; range: 8.0-90.7), AS (median: $37.1 \mathrm{IU} \mathrm{L}^{-1}$; range: $12.2-88.1$ ) and ReA (median: $38.4 \mathrm{IU} \mathrm{L}^{-1}$; range: $16.0-69.1)$ patients was statistically significantly increased compared to the control group (Figure 2a). Concentration of DPP IV in PsA (median: $245.9 \mathrm{ng} \mathrm{mL} \mathrm{mL}^{-1}$; range: $139.3-418.3$ ) and AS (median: $242.1 \mathrm{ng} \mathrm{mL}^{-1}$; range: $107.2-445.1$ ) patients was statistically significantly increased in comparison to ReA

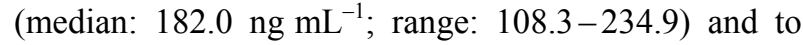
the control group (Figure 2b).

No statistically significant difference of serum DPP IV activity or concentration was observed between patients with clinically active disease and those in remission (Table 3) in RA or SpA groups. There was no statistically significant correlation between DPP IV activity or concentration and laboratory parameters such as CRP, as well as disease activity indices DAS 28 or BASDAI, except for ReA group where DPP IV activity correlated positively with CRP (Spearman's test: $r=$ $0.52, p<0.050)$.

\section{DISCUSSION}

The pathophysiology of SpA and RA is not completely understood, but it is believed that the genetic predisposition, environmental factors and immune response, including inflammatory mediators mainly produced by activated $\mathrm{T}$ lymphocytes and macrophages, participate in complex mechanisms at systemic and local level and lead to disease development. Both diseases are chronic inflammatory autoimmune disorders and better monitoring of their progression, evaluation of disease activity and monitoring of therapeutic efficiency is indeed necessary. The diagnostic algorithm of $\mathrm{SpA}$ diseases is complex and based on clinical signs, laboratory parameters and radiographic findings. Therefore, the diagnosis is often delayed up to eight years from symptom onset. ${ }^{17}$

According to our results and previously published data, laboratory abnormalities in SpA patients are non- 

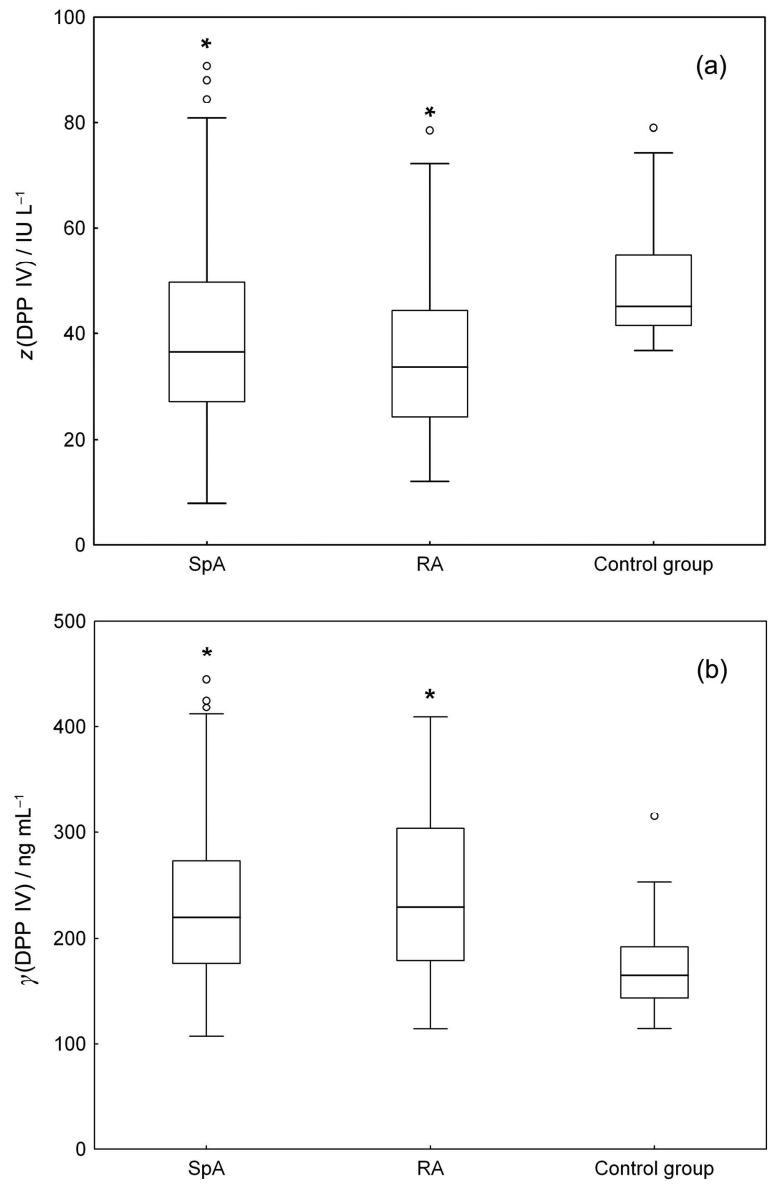

Figure 1. Serum dipeptidyl peptidase IV (DPP IV) activity (a) and mass concentration (b) in spondyloarthritides (SpA) and rheumatoid arthritis (RA) patients and control group. Box plots represent the lower quartile, median and upper quartile. The ends of the lines indicate the $10^{\text {th }}$ and $90^{\text {th }}$ centiles. $\circ$ represent extreme values, below the $10^{\text {th }}$ or above $90^{\text {th }}$ centile. * represent statistically significantly different compared to control group, $p<0.050$.

specific and not as useful as the clinical presentation for diagnosis of specific disease. The present results show that patients with active SpA have increased CRP and ESR values, as well as patients with active RA. Since CRP and ESR are the two most commonly used clinical markers nowadays and show very low sensitivity and specificity ${ }^{17}$ we investigated whether DPP IV could be used as a novel distinguishing and/or disease activity SpA marker.

As far as we are aware, the present study is the first to demonstrate changed serum DPP IV activity and antigen level in adult patients with SpA. Our results revealed a decrease in serum DPP IV activity in patients with $\mathrm{SpA}$, as well as those with RA, compared to the control group. Our findings are in agreement with the findings of Busso et al. ${ }^{18}$ who also showed a decrease
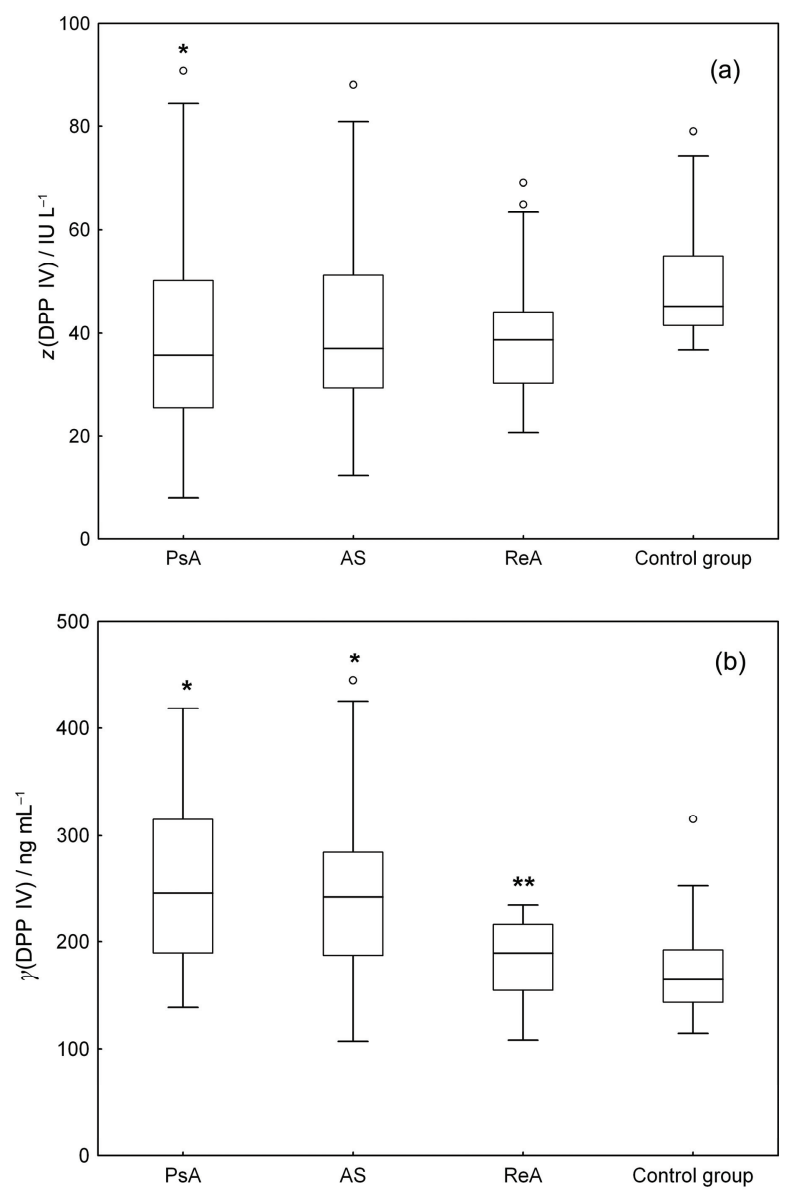

Figure 2. Serum dipeptidyl peptidase IV (DPP IV) activity (a) and concentration (b) in patients with spondyloarthritides (SpA): psoriatic arthritis (PsA), ankylosing spondylitis (AS) and reactive arthritis ( $\mathrm{ReA})$; and control group. Box plots represent the lower quartile, median and upper quartile. The ends of the lines indicate the $10^{\text {th }}$ and $90^{\text {th }}$ centiles. $\circ$ represent extreme values, below the $10^{\text {th }}$ or above $90^{\text {th }}$ centile. $*$ represents statistically significantly different compared to control group, $p<0.050 . \star \star$ represents statistically significantly decreased compared to PsA and AS patients, $p<0.050$.

in DPP IV activity in RA patients. Since we observed no statistically significant difference in serum DPP IV activity and concentration between patients with SpA and RA, it can be concluded that this molecule could not be used as a specific differentiating marker. Moreover, our results showed no statistically significant difference in serum DPP IV activity among SpA groups of patients. Therefore, it seems that serum DPP IV activity could not be used as a specific serum marker within SpA diseases.

DPP IV is predominantly present in a soluble form in blood and other body fluids and also as an antigen on the membrane of $\mathrm{T}$ lymphocytes. ${ }^{19}$ The precise origin and the physiological role of soluble DPP IV in plasma 
or other biologically important fluids is unclear. Even though we demonstrated a reduced serum DPP IV activity, the immunodetection showed increased DPP IV concentration in both SpA and RA patients, when compared to control group. Nevertheless, the decrease in DPP IV activity could not be explained by lower circulating levels of DPP IV since we demonstrated an increased serum DPP IV concentration. This discrepancy could partially be explained with the process of glycosylation which causes structural alterations of DPP IV and could prevent its removal from the circulation. Although the most of published data indicate that DPP IV glycosylation is not a prerequisite for catalytic activity, homodimer formation or adenosine deaminase binding capacity, some reports show opposite evidence. ${ }^{20,21}$ In line with the findings by Cuchacovich et al. ${ }^{22}$ it can be suggested that sialylation (a type of glycosylation) of specific sites of the enzyme might be involved as an underlying mechanism of the decreased DPP IV activity determined in serum of RA patients. Therefore, since we found that serum DPP IV activity and concentration in SpA patients were similar to those in RA patients, we speculate that such mechanism could also be present in SpA patients. However, further studies should be done in order to validate this suggestion.

DPP IV as a serine peptidase is able to cleave numerous biologically important molecules, including inflammatory mediators such as RANTES, SDF-1 $\alpha$, vasoactive intestinal peptide and substance $P{ }^{23}$ Therefore, it can be suggested that changes of bioavailability of DPP IV substrate could influence the proliferation and recruitment of immune cells including the changing of the Th1/Th2 immune balance. Therefore, the significance of the established reduced serum DPP IV activity is proposed. Interleukins and chemokines are released by different cells and their receptors are present on the surface of those cells. Hence, in the pathogenesis of inflammatory arthritis, each chemokine may induce different effects, depending on which receptor it bounds in a particular environment. ${ }^{24}$ It has been reported that SDF- $1 \alpha$ and its receptor CXCR4 are supposed to play a crucial role in inflammatory cells recruitment. There is an established assumption that SDF-1 $\alpha$ cleavage is mediated by DPP IV because N-terminally intact form was found in serum of CD26 deficient mice, whereas in serum of wild-type mice, SDF- $1 \alpha$ is mostly converted to the inactive truncated form. ${ }^{18}$

Apart through its enzymatic function, DPP IV may also potentially modulate the immune response by its role as a co-stimulatory molecule or its ability to interact with the cytoplasmatic domain of CD45 and adenosine deaminase. ${ }^{25}$ In $\mathrm{SpA}$ and RA, different cellular subsets are observed at sites of inflammation, including $\mathrm{CD}^{+}$and $\mathrm{CD}^{+} \mathrm{T}$ lymphocytes as well as B cells, mac rophages and neutrophils. ${ }^{26-28}$ On the other hand, it has been reported that in patients with active RA the number of peripheral blood $\mathrm{CD}^{+} \mathrm{T}$ lymphocytes and monocytes expressing DPP IV is increased. ${ }^{29,30}$ Thus, it could be suggested that the expression of CD26 on T lymphocytes in RA or SpA patients may interfere with activation and migration of these or some other inflammatory cells. Furthermore, it was shown that various competitive, as well as uncompetitive DPP IV inhibitors were effective in alleviating inflammation, including experimental models of RA. ${ }^{31}$ However, some of these inhibitors showed anti-arthritic effects in DPP IV deficient animals, suggesting the potential importance of DPP IVlike enzymes in the pathogenesis. ${ }^{32}$ Our results confirm the previously proposed theory that other proteins which posses DPP IV-like activity are active in serum and could be involved in the development of rheumatoid diseases.

Taking in consideration the fact that inflammation is the major driver of disease activity, along with the evidence of the importance of DPP IV in modulation of immune response, we have tried to find a causal connection between them. Since we have observed no statistically significant difference in serum DPP IV activity and antigenic level between patients with active disease and those in remission in SpA and RA, it can be suggested that this molecule could not be used as a disease activity marker.

\section{CONCLUSIONS}

This study reveals new data about serum DPP IV activity and antigen level in adult SpA patients. A decreased serum DPP IV activity was found in SpA and RA patients compared to the control group, while the DPP IV concentration was increased. Moreover, our results showed no statistically significant difference in serum DPP IV activity or concentration between SpA and RA patients. The results of our study indicate that serum DPP IV activity could not be used as a specific noninvasive clinical marker for differentiation of SpA diseases, but could be potentially used as a non-specific inflammatory marker. Since we demonstrated changes in serum DPP IV activity and concentration in SpA patients and taking in consideration that non-selective DPP IV inhibitors showed potential anti-arthritic effects, this molecule could not be excluded as a potential mediator in inflammatory arthritis development.

Acknowledgements. This work was supported by the grant No. 062-0061245-0213, Ministry of Science, Education and Sports of the Republic of Croatia. The authors would like to thank Josip Laginja, BSc for sample collection and Ms. Dolores Kovačić for laboratory assistance. 


\section{REFERENCES}

1. T. Rooney, E. Murphy, M. Benito, P. Roux-Lombard, O. FitzGerald, J. M. Dayer, and B. Bresnihan, Ann. Rheum. Dis. 63 (2004) 1393-1398.

2. B. Kwiatkowska and A. Filipowicz-Sosnowska, Pol. Arch. Med. Wewn. 119 (2009) 60-65.

3. D. D. Gladman, J. Rheumatol. Suppl. 83 (2009) 4-8.

4. M. A. Brown, Curr. Opin. Rheumatol. 21 (2009) 318-323.

5. P. S. Kim, T. L. Klausmeier, and D. P. Orr, J. Adolesc. Health 44 (2009) 309-315.

6. C. Salvarani and W. Fries, World J. Gastroenterol. 15 (2009) 2449-2455.

7. P. P. Tak and B. Bresnihan, Arthritis Rheum. 43 (2000) 26192633.

8. R. Mentlein, Int. Rev. Cytol. 235 (2004) 165-213.

9. S. Struyf, P. Proost, D. Schols, E. De Clercq, G. Opdenakker, J. P. Lenaerts, M. Detheux, M. Parmentier, I. De Meester, S. Scharpe, and J. Van Damme, J. Immunol. 162 (1999) 4903 4909.

10. M. Hegen, J. Kameoka, R. P. Dong, C. Morimoto, and S. F. Schlossman, Adv. Exp. Med. Biol. 421 (1997) 109-116.

11. M. Dougados, S. van der Linden, R. Juhlin, B. Huitfeldt, B. Amor, A. Calin, A. Cats, B. Dijkmans, I. Olivieri, G. Pasero et al., Arthritis Rheum. 34 (1991) 1218-1227.

12. J. M. Moll and V. Wright, Semin. Arthritis Rheum. 3 (1973) 55-78.

13. J. Zochling, D. van der Heijde, R. Burgos-Vargas, E. Collantes, J. C. Davis, Jr., B. Dijkmans, M. Dougados, P. Geher, R. D. Inman, M. A. Khan, T. K. Kvien, M. Leirisalo-Repo, I. Olivieri, K. Pavelka, J. Sieper, G. Stucki, R. D. Sturrock, S. van der Linden, D. Wendling, H. Bohm, B. J. van Royen, and J. Braun, Ann Rheum. Dis. 65 (2006) 442-452.

14. F. Banal, M. Dougados, C. Combescure, and L. Gossec, Ann. Rheum. Dis. 68 (2009) 1184-1191.

15. F. C. Arnett, S. M. Edworthy, D. A. Bloch, D. J. McShane, J. F. Fries, N. S. Cooper, L. A. Healey, S. R. Kaplan, M. H. Liang, H. S. Luthra et al., Arthritis Rheum. 31 (1988) 315-324.

16. W. Kreisel, R. Heussner, B. Volk, R. Buchsel, W. Reutter, and W. Gerok, FEBS Lett. 147 (1982) 85-88.
17. M. Rudwaleit, D. van der Heijde, M. A. Khan, J. Braun, and J. Sieper, Ann. Rheum. Dis. 63 (2004) 535-543.

18. N. Busso, N. Wagtmann, C. Herling, V. Chobaz-Peclat, A. Bischof-Delaloye, A. So, and E. Grouzmann, Am. J. Pathol. 166 (2005) 433-442.

19. C. Morimoto and S. F. Schlossman, Immunol. Rev. 161 (1998) 55-70

20. K. Aertgeerts, S. Ye, L. Shi, S. G. Prasad, D. Witmer, E. Chi, B. C. Sang, R. A. Wijnands, D. R. Webb, and R. V. Swanson, Protein Sci. 13 (2004) 145-154.

21. W. A. Weihofen, J. Liu, W. Reutter, W. Saenger, and H. Fan, J. Biol. Chem. 279 (2004) 43330-43335.

22. M. Cuchacovich, H. Gatica, S. V. Pizzo, and M. GonzalezGronow, Clin. Exp. Rheumatol. 19 (2001) 673-680.

23. R. Mentlein, Regul. Pept. 85 (1999) 9-24.

24. K. J. Katschke, Jr., J. B. Rottman, J. H. Ruth, S. Qin, L. Wu, G. LaRosa, P. Ponath, C. C. Park, R. M. Pope, and A. E. Koch, Arthritis Rheum. 44 (2001) 1022-1032.

25. R. P. Dong, K. Tachibana, M. Hegen, Y. Munakata, D. Cho, S. F. Schlossman, and C. Morimoto, J. Immunol. 159 (1997) 60706076.

26. D. Baeten, E. Kruithof, L. De Rycke, A. M. Boots, H. Mielants, E. M. Veys, and F. De Keyser, Arthritis Res. Ther. 7 (2005) R359-R369.

27. D. Baeten, P. Demetter, C. Cuvelier, F. Van Den Bosch, E. Kruithof, N. Van Damme, G. Verbruggen, H. Mielants, E. M. Veys, and F. De Keyser, Ann. Rheum. Dis. 59 (2000) 945-953.

28. L. Laloux, M. C. Voisin, J. Allain, N. Martin, L. Kerboull, X. Chevalier, and P. Claudepierre, Ann. Rheum. Dis. 60 (2001) 316-321.

29. T. Ellingsen, N. Hornung, B. K. Moller, J. Hjelm-Poulsen, and K. Stengaard-Pedersen, Scand. J. Immunol. 66 (2007) 451-457.

30. R. Gerli, C. Muscat, A. Bertotto, O. Bistoni, E. Agea, R. Tognellini, G. Fiorucci, M. Cesarotti, and S. Bombardieri, Clin. Immunol. Immunopathol. 80 (1996) 31-37.

31. S. Tanaka, T. Murakami, N. Nonaka, T. Ohnuki, M. Yamada, and T. Sugita, Immunopharmacology 40 (1998) 21-26.

32. A. Sedo, J. S. Duke-Cohan, E. Balaziova, and L. R. Sedova, Arthritis Res. Ther. 7 (2005) 253-269. 